\title{
Multiculturalism and multiethnicity in the cityscape: The case of Białystok religious landscape
}

\author{
Justyna LiRO ${ }^{1}$, Julia SOŁJAN ${ }^{2}$, ElżBieta BILSKA-WODECKA ${ }^{1}$ and Izabela SO
}

\begin{abstract}
Białystok is the capital of a province in north-eastern Poland. In the past the city featured ethnic, cultural and religious diversity, Roman Catholics, Eastern Orthodox, Protestants, and Jews coexisted here in the $18^{\text {th }}$ and $19^{\text {th }}$ centuries. The Jewish communities shaped the city's religious landscape and local identity significantly since the second half of the $19^{\text {th }}$ century and until World War II when they constituted half of the city's population. This was the biggest minority group among Polish cities. The post-Jewish landscape became invisible and silent by now. It was the result of the Nazi policy of extermination, and the anti-Semitic policy of the communist Polish authorities, as well as the attitude of Polish society towards the Jewish minority until the late 1960s. From among almost 60 synagogues and prayer houses which operated before the war, only three have survived, but they have not been in use for religious service for a long time. Białystok has also been inhabited by the so-called Polish Tatars. The Muslim community, which for centuries consisted mainly of Polish Tatars, is increasingly visible in the city, which is also the seat of Muslim Religious Union, the largest Muslim union in Poland. There is also the Białystok Centre of Islam and a house of prayer. Today's religious landscape of the city is mostly formed by both Roman Catholic and Orthodox churches. As a result of the city's demographic and spatial development, the number of churches has grown significantly as compared to the inter-war period. The strongest and the most visible qualitative changes were observed after World War II. Multiculturalism is still important asset of the city. This paper presents the transformation of the cultural and religious landscape of Bialystok in the context of the impact of the politics and ideology from the $19^{\text {th }}$ century to the present. It also highlights the importance of multiculturalism in the city landscape for the promotion and development of tourism and city branding.
\end{abstract}

Keywords: multiculturalism, multiethnicity, diversity, religious landscape, Jewish heritage, Białystok, Poland.

\section{Introduction}

Today's Białystok is one of the most important cities in north-eastern part of Poland. For centuries, the majority of large Polish cities were diverse in economic, ethnic and religious terms. Since its foundation by the Branickis in 1691, Białystok were gaining its multicultural character, among others, due to the policy of its owners. Originally, it was a private town and in 1802 it was sold and passed onto Prussia, and in 1807 it became part of Russia. The formation of Białystok as a multicultural city at the beginning of the $19^{\text {th }}$ century was significantly influenced by political factors and the dynamic development of textile industry.

The co-existence of populations of three religions, i.e. Catholic, Jewish and Orthodox, was of great importance in the history of Białystok. Despite the changing political situation, until 1939 the city had maintained its multi-ethnic and multi-religious character. It is not accidental that the creator of Esperanto, Ludwik Zamenhof, came from Białystok. As a child, observing people speaking different languages, he saw in this the main source of conflict between

\footnotetext{
${ }^{1}$ Institute of Geography and Spatial Management, Jagiellonian University, ul. Gronostajowa 7, 30-387 Krakow, Poland. Corresponding author's e-mail: justyna.liro@uj.edu.pl

${ }^{2}$ Faculty of Polish Studies, Jagiellonian University, ul. Gołębia 16, 30-001 Krakow, Poland.
} 
them. He decided to create a new language, providing everyone with the ability to communicate easily. Already as a 10 -yearold boy, he wrote the play The Tower of Babel or a Biatystok tragedy in five acts (WYszowsKA, I. and JĘDRYSIAK, T. 2014).

After 1945, significant changes took place in the ethnic and religious structure of Białystok as a result of the Holocaust and, next, the policy pursued by the communist authorities of Poland. The Jewish community completely vanished from the city's space. Polish Tatars, who began to settle in Białystok in the 1960s, became a new religious group. The city was also settled by populations from the surrounding villages, often Orthodox and with Belarusian origins, yet without a sense of national consciousness, or hiding it because of the prevailing belief that in Białystok it is appropriate to be a Pole (SADowski, A. 2006). It was the outcome of the policy implemented by the communist government pursuing the elimination of the signs of minority groups from public life, and the development of a homogeneous Polish society. It was only the political transformation and systemic changes after 1989 that resulted in a change in the attitude of plotics towards minority groups, which ceased to be perceived as "non-Polish and hostile". In the meantime, multiculturalism became an asset of many urban centres, and also the role of the cultural heritage associated with it became more and more recognized. This is also the case in Białystok. The Strategy for the development of the city of Biatystok for 2011-2020 plus reads as follows: "A very important criterion for the adoption of spatial solutions at any scale must be the consideration of the conditions stemming from historical heritage and cultural aspects. Only in this way can we ensure the preservation, and where necessary, restoration of identity of the city's space" (Strategia Rozwoju Miasta Białegostoku... 2010, p. 96).

The term 'multiculturalism' in itself is vaguely defined (Bнiкhu, P. 2002; Trotman, C. 2002; Modood, T. 2007). The issue of multiculturalism appeared in politics after
1945 and was most often analysed in the context of political and social consequences (Rex, J. and Singh, G. 2003; Arneil, B. 2006; Banting, K. and Kymlicka, W. 2006; Hero, R. and Preuhs, R. 2006; Laden, A.S. and Owen, D. 2007; Phillips, A. 2007; Arneil, B. and MacDonald, F. 2016). There is no clear definition of multiculturalism in the literature either. Depending on needs, each researcher defines it differently. With regard to Białystok, the authors of this paper believe that the best perspective is the one proposed by TIRYAKIAN, E.A. (2003): "I begin by the assertion that the term 'multicultural' is an empirical demographic condition referring to a society (which may or may not be a nation-state but may also include an empire) having two or more ethnic groups, each having cultural traits that may have some overlap with the other group(s), yet is distinctive enough to form a different cultural identity and community."

This concept of multiculturalism is also referred to by Marotta, V. (2007). Multiculturalism is not a new phenomenon. It can be analysed at different spatial (e.g. country, region, city) and temporal scales, in historical or contemporary terms. Examples of multicultural empires have been known since ancient times (e.g. Alexander the Great's empire, Roman Empire, Ottoman Empire, Commonwealth of Nations). Today, we can also find multicultural states, wellknown examples are, inter alia, the United States, Canada, Germany, Australia (Rex, J. and SingH, G. 2003), Belgium, Switzerland (Tiryakian, E.A. 2003). There are great number of examples for cities inhabited by different ethnic, religious and language groups, and there have been many examples of city districts in the history which were inhabited by minorities, such as the Jewish Quarter of Alexandria, or the Ghetto Nuovo in Venice.

A city's multiculturalism can be analysed from many different aspects, including economic, political, and social ones, as well as that of national heritage. The first papers dealing with the multiculturalism of cities were mostly statistical and descriptive, and the differences were presented mainly in the 
religious context. It was first Richard FLORIDA (2002) who drew the attention to its economic impacts. The author pointed out in his work that multiculturalism can contribute to the development of creativity which can indirectly influence the growth of local economy. The political aspect of multiculturalism is particularly relevant today as it addresses the issue of integration of different social groups with distinct linguistic, religious or ethnic character.

In Polish literature, there is no uniform definition of multiculturalism either common to all researchers. The traditional understanding of this term is related to the pattern of social relationships in which a number of different ethnic, national, or religious groups with distinct cultures inhabit a given territory. Such a perspective on multiculturalism in most cases leads to the presentation of the coexistence of different cultures as a harmonious, conflict-free, coexistence of equal communities. Newer and more complex definitions of multiculturalism are more diverse. One of them by SADowski, A. (2013) defines multiculturalism as a system of social relations based on long-term and lasting intercultural relations and integration within a single society of different cultural groups that together form a qualitatively new culturally diverse whole. Another definition is provided by DolińsKa, K. and Makaro, J. (2013), according to whom multiculturalism can be viewed on four levels:

1. "real diversification",

2. consciousness (awareness of the presence of others experienced in everyday life),

3. political (multiculturalism or political multiculturalism),

4. marketing (marketing use of multiculturalism) (PAsIEKA, A. 2013).

Yet, another aspect of the phenomenon of multiculturalism was exposed by ŁAGUNARaszKiEwicz, K. (2012) who understood multiculturalism as cultural pluralism, in which "each culture has its unique values to offer the others, and it is only through the coexistence of this diversity that human potential is fully realized." In this study we apply
ŁAGUNA-RASZKIEWICZ's perspective and we carry out an analysis of multiculturalism in the context of national heritage in the case of Białystok. Thus, multiculturalism means cultural diversity, i.e. the occurrence of a certain number of cultures in a particular area. Multiculturalism is understood here as the co-existence of many cultures, which may significantly increase the tourist attractiveness of a particular area, and thus become an impulse for the creation of a tourist function and the promotion of the area for cultural tourism (CAFFYN, A. and Lutz, J. 1999; PIZAM, A. 1999; Reisinger, Y. 2009; Puchnarewicz, E. 2010; Duridywka, M. and Kociszewski, P. 2013; Irimiás, A. and Michalkó, G. 2013). The occurrence and co-existence of two or more groups with different cultural values within the same area seems to be important factor for the development of tourism. The multiculturalism of cultural heritage supported by actions for its protection and promotion may be an important factor supporting the development and tourism in the region. The main aim of this paper is to present the multiculturalism of Białystok visible in the landscape of the city. Attention will be paid both to the currently functioning minority groups, and to the way to perpetuate the memory of the formerly very numerous, and now almost non-existent communities, mostly Jewish.

\section{The denominational structure of Białystok}

Over centuries, the denominational structure of Białystok changed radically, with the biggest changes occurring in the post-World War II period: After 1945 Catholics became the dominant religious group in the city, along with the presence of the Orthodox and Muslims as religious minorities. Followers of the Orthodox Church represent about 12 per cent of the city's population, constituting one of the largest Orthodox communities in Poland. The number of Muslims is estimated to be at 2,000 people, most of them being Polish Tatars historically associated with the Tatar settlements in the Podlasie region, dating 
back to the $17^{\text {th }}$ century (SADowsKI, A. 2013). In addition to these groups, the cultural heritage of the city was also co-created by other religious communities, especially the Jews. At the beginning of the $20^{\text {th }}$ century, Białystok was a predominantly Jewish town, and in the interwar period, following the regaining of independence by Poland in 1918, a Polish-Jewish one (SAdowski, A. 2013).

The first mention of the Jewish population in Białystok dates back to 1658. It was a small group belonging to the kehilla in Tykocin (DAcewicz, L. 1997). After Białystok gained town status in 1691, the Branickis encouraged Jews to settle the city by building them houses and shops (Shmulewitz, I. 1982). In 1711, the first wooden synagogue was founded in the city, and in 1745 Klemens Branicki made the rights of the townspeople and the Jews in Białystok equal. In 1765, 756 Jews lived in the city constituting approximately 22 per cent of the total population. At the end of the $18^{\text {th }}$ century, Białystok counted 6,200 people, including 4,100 Catholics, 1,900 Jews, approx. 150 Orthodox, and 30 Uniates (DAcewicz, L. 1997). In the following century, the Jewish community grew rapidly. The period of its greatest growth was at the end of the $19^{\text {th }}$ century and in the first decade of the $20^{\text {th }}$ century, when from 41,900 people $(63.5 \%$ of the total population) in 1897, their number increased to 70,500 (82.0\% of the total population) in 1911. In 1921, Jews still constituted the majority of Białystok's inhabitants (51.6\%), but ten years later their proportion fell to 42.3 per cent (BILsKa-WodecKA, E. 2012; Byelostok 20022011). The reasons for this phenomenon must be sought, among others, in the inflow of the Polish population after 1918, and the emigration of Jews to Palestine, as well as the change of the city boundaries and enlargement of its area. At that time, the Roman Catholic Church ranked first in terms of the number of believers $(41,500$ and $45.5 \%$ of the total population). The most tragic period in the history of the Jews in Białystok was the Holocaust. In 1941, on 27 June, the Nazis set fire to the Great Synagogue, inside which they had previously locked at least 700 Jews. On 1 August
1941 , about 60,000 Jews were deported to the ghetto, the majority of whom were killed and the rest deported to concentration and labour camps (KLIMcZuK, A. 2012).

After the end of the war, in 1946, approximately 1,500 people of the Jewish denomination lived in Białystok, but many of them stayed there only temporarily, on their way to Palestine or to other Polish regions. In 1951, only 165 Jews lived in the city (SADowsKa, J. 2015). The last wave of emigration to Israel took place in the late 1960s when 100 people of Jewish origin left the city and, thus, the centuries-old Jewish community in Białystok virtually ceased to exist.

Today, the largest religious minority in the city is connected with the Polish Autocephalous Orthodox Church. The institutional presence of the Eastern Rite in Białystok is not confirmed in historical sources before the $18^{\text {th }}$ century. However, in neighbouring Dojlidy (today part of Białystok), an Orthodox temple existed already in 1571. The first Orthodox church in Białystok, St. Nicholas' church ${ }^{3}$, was founded by the owner of the city, Jan Klemens Branicki, as a chapel of ease in the Dojlidy parish. The earliest mention of it dates back to 1727, and was made on the occasion of making an offering by the clergyman holding pastoral ministry in it. However, there are reasons to date the establishment of the first Orthodox church in Białystok earlier, i.e. at the end of the $17^{\text {th }}$ century, or at the turn of the $17^{\text {th }}$ and $18^{\text {th }}$ centuries (Czyżewski, P. 1997). Sosna, G. and Troc-Sosna, A. (2004) indicate that such a situation might be related to the denomination of the rulers of the city (the Branickis considered themselves zealous Catholics), since in the sources there is no mention of the erection of this Orthodox church for subjects (Sosna, G. and Troc-Sosna, A. 2004).

\footnotetext{
${ }^{3}$ Initially, it was a Greek-catholic Uniate church. In 1596 in Brest, the Orthodox Church in Poland entered into union with the Catholic Church, under which some Orthodox bishops adopted the Catholic doctrine and accepted the supremacy of the pope. The last Uniate churches in northern Podlasie existed until 1839 when, by the Tsar's decision, they were incorporated into the Orthodox Church.
} 
In the $19^{\text {th }}$ century, when Białystok formally belonged to Russia, the number of Orthodox Christians in the city increased significantly. As in other large cities of the Russian partition, a significant proportion of Orthodox Christians were ethnic Russians working in the state administration at various levels. The second group of the Russian Orthodox Christians included custom-officers, and the third - soldiers and families of the commanding personnel. The number of the police and army troops stationed on the Polish territory increased significantly after the January Insurrection and the revolution in 1905. During World War I, most of the Orthodox Russians left the city (BILSKAWodeckA, E. 2012).

The native Orthodox population was not associated with the Tsarist administration. They were mainly people from Belarus and Poland. In 1897, the Orthodox constituted approximately 12 per cent of the total population (Table 1). After a period of decline in the years 1910-1921, when their number was less than 5,000, in 1931 ca. 7,500 Orthodox believers were recorded again, half of whom, at least officially, were Poles (Kalina, M.
1995). Today's Orthodox community (approx. 35,000 people) was formed mainly in the post-war period in connection with the development of the city and a strong migration of people from rural areas and smaller towns to the centre of the region, Białystok.

The presence of Protestants in Białystok is associated with the city's belonging to Prussia (1795-1807). In the early $19^{\text {th }}$ century, a group of soldiers from Saxony settled down here, mainly specialists in weaving and spinning, who set up numerous workshops, thus, giving rise to the development of textile industry. Prussian authorities made efforts to establish a Protestant religious community. This happened in 1804 when the number of Protestants in the city and its surroundings was approximately 1,000 people, which seems to be highly overestimated (MAєEK, A. 1999). The combination of the modest capital of the settlers with the local Jewish capital resulted in fact that Białystok became the third largest centre of textile industry in Russia, after Moscow and Łódź.

In the first three decades of the $20^{\text {th }}$ century, the number of Protestants declined steadily, from about 3,400 in 1910, to 2,500 in 1931. In

Table 1. Religious structure of Białystok (1897-2005)

\begin{tabular}{|c|c|c|c|c|c|c|c|}
\hline \multirow{2}{*}{ Confession } & \multicolumn{7}{|c|}{ Population } \\
\hline & 1897 & 1911 & 1921 & 1931 & 1960 & 2005 & 2015 \\
\hline Roman Catholic & 12,519 & 7,740 & 29,673 & 41,493 & 46,000 & 202,201 & 186,970 \\
\hline Orthodox & 7,947 & 4,300 & 4,770 & 7,502 & 5,000 & 34,695 & 38,400 \\
\hline Protestant & & 3,440 & 2,550 & 2,633 & 412 & 860 & 1,800 \\
\hline Judaism & 41,905 & 70,520 & 39,602 & 39,165 & - & - & - \\
\hline Other & 3,661 & .. & 18 & 158 & 300 & 1,300 & 2,900 \\
\hline No affiliation* & & .. & 39 & 24 & 69,209 & 49,638 & 65,911 \\
\hline Total population & 66,032 & 86,000 & 76,792 & 91,101 & 120,921 & 288,694 & 295,981 \\
\hline \multicolumn{8}{|c|}{ Population in percentage } \\
\hline Roman Catholic & 18.96 & 9.00 & 38.64 & 45.55 & 38.04 & 70.04 & 63.21 \\
\hline Orthodox & 12,04 & 5.00 & 6.21 & 8.23 & 4.13 & 12.02 & 13.00 \\
\hline Protestant & & 4.00 & 3.32 & 2.89 & 0.34 & 0.30 & 0.60 \\
\hline Judaism & 63.46 & 82.00 & 51.57 & 42.99 & - & - & 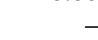 \\
\hline Other & 5.54 & .. & 0.02 & 0.17 & 0.25 & 0.45 & 0.98 \\
\hline No affiliation* &.. & .. & 0.05 & 0.03 & 57.23 & 17.19 & 22.21 \\
\hline Total population & 100.00 & 100.00 & 100.00 & 100.00 & 100.00 & 100.00 & 100.00 \\
\hline
\end{tabular}

*The difference between the total population and the total number of persons belonging to religious associations shown above. .. = No data. Source: Author's work based on Bilska-Wodecka, E. (2012) and data of religious associations. 
this group, Lutherans were the most numerous. Today, the Protestant community is relatively small (about 800 people) and is represented by several Protestant denominations (Baptists, Lutherans, Adventists, Pentecostals).

The rapid increase in the number of Catholics was visible from the 1920s (BILSKAWodeckA, E. 2012) and according to census figures in 1931 they were already the largest religious community in Białystok ${ }^{4}$. The beginnings of the Roman Catholic Church in the city go back to the establishment of a settlement here in the first half of the $15^{\text {th }}$ century. Over a hundred years later, in 1547 the first wooden Catholic church was erected. Following the burning of the temple in 1617, the construction of a brick church was started. After its completion in 1626, an independent parish of the Assumption of the Blessed Virgin Mary was established in Białystok. At the end of the $19^{\text {th }}$ century, the church was expanded by erecting an addition which was much bigger than the current temple itself. This action was dictated by the refusal of the Russian authorities to erect a new temple. In the interwar period, in the restored Polish state, St. Roch's parish was founded and its new modernist church was erected. However, the period of the strongest development of the parish network, and the creation of new objects of worship, began in the 1970s.

The Tatars, present in the Podlasie region since the second half of the $17^{\text {th }}$ century, did not appear in Białystok in larger numbers until the late 1950s and 1960s. According to the 1921 census, there were only 11 people of Tatar origin in the city (Miśkiewicz, A. 2011). The development of the Tatar community in Białystok was the result, among others, of the territorial changes after World War II, when most of the Tatar people found themselves in the Soviet Union, and they started to emigrate from these areas to Poland as well as the influx of people from the rural areas of the Białystok province. Immediately after the end of the war, the Tatars started to migrate

\footnotetext{
${ }^{4}$ However, the difference between the share of the Jewish followers and the Catholics was very small at that time, within the range of 2 per cent.
}

mainly towards the formerly German areas of northern and western Poland (incorporated into the Polish state in 1945). Unable to settle in the new conditions, however, they often left these regions and moved back to Białystok. In 1964, the Białystok community of Polish Tatars counted 285 residents (approx. 90 families). In 1962, a separate religious community was established in the city. Within 20 years, the number of Tatars increased almost sixfold, reaching 1,800 of the faithful in the Białystok community in 1985. Since then, the size of the community has remained at this level, with a slight upward trend (approx. 2,000 Muslims live nowadays in the city).

Concluding the discussion of the religious structure of Białystok, it is worth noting that it is still a relatively diversified city according to religion, standing out among other Polish cities especially regarding the high proportion of the Orthodox people, and the relatively low proportion of Catholics (as for Polish conditions), even though they are still the absolutely dominant group in Białystok.

\section{Religious heritage in the urban landscape}

The centuries-old coexistence of different religious groups in the city is not without impact on the urban fabric and the emerging urban landscape. The preservation of the heritage sites has depended on numerous factors, mainly of historical, political and social characters. Białystok is a showcase where the discussed factors caused within quarter of a century (1939-2015), fundamental transformations both in the composition of its residents and the organization of urban space. The occurring changes were multidirectional, of which three main phases can be distinguished in chronological order:

1. The period of German occupation: extermination of the Jewish population, destruction of most Jewish objects of the cult, including the burning of the Great Synagogue, the formation and liquidation of the Białystok ghetto. Among the many synagogues only 
three have been preserved, i.e. the Cytron, Piaskower and one in Branickiego street.

2. The period of the communist rule (19451989): as a result of the one-nation state policy, Białystok became a typical Polish city. After the war the remaining small Jewish community left the city, and its few institutions finally ceased to function in the 1960s. Thus, the Jewish district and other places associated with this religious group vanished from the city-scape. The authorities deliberately pursued a 'policy of oblivion,' both in space and in the awareness of the city's new residents. At the same time the communist ideology and its aesthetic aspects became widespread, simultaneously religious communities were not fully guaranteed their rights. Despite the demographic and territorial development of Białystok, authorities did not allow the construction of Orthodox and Catholic churches for a long time. It was only in the 1970s and 1980s that new objects of worship began to appear in the city landscape.

3. The period of political transformation to the present day: a fundamental change in the policy towards national, ethnic and religious minorities where the multicultural nature of the city tended to become an asset for urban development. The effect of this is, on the one hand, the development of religious communities and associations, i.e. the extension of the parish network and erection of objects of worship of the Catholic and Orthodox Churches, the development of the Muslim community and, on the other hand, the displaying of their cultural heritage in the city, among others, through the creation of thematic trails.

According to the above mentioned distinctions, the beginnings of significant changes in the urban landscape of Białystok can be associated with the outbreak of World War II in 1939. In the second half of September 1939, Białystok came under Soviet occupation. At the same time, many Jewish refugees from the General Government and the territories occupied by Germany, among others from Łódź or Warsaw, arrived in the city. The Soviets did not persecute the Jews in any special way, however, they did close down Jewish religious institutions and banned political parties. The Jewish population was also affected by deportations to the Soviet Union. However, it was only the outbreak of the German-Soviet War in 1941 and the subsequent German occupation that resulted in the most tragic events in the city's history. The Germans entered Białystok at the end of June 1941 and within a few months damaged and destroyed it irreversibly. On 27 June, the famous murder of Jews in the flames of the torched Great Synagogue took place. The biggest Jewish cemetery was also destroyed.

It is worth noting that, under these circumstances, the Jewish population attempted to lead at least a substitute of normal life. In the ghetto, factories operated, vegetables were grown, and cattle were grazed. An attempt to engage in armed combat was also made, but the uprising was suppressed after a few days. Those who survived were then deported by the Nazis to the concentration camps in Majdanek and Treblinka (Lechowski, A. 2009). Shaped by centuries, Jewish Białystok was, like its residents, doomed to annihilation.

In the first years after the war, Jewish survivors still hoped against all hope for the possibility to rebuild their city. Organizations embracing pre-war emigrants from Białystok, among others the Białystok Centre in New York founded in 1919, allocated significant funds for this purpose (Koвrin, R. 2014). The initial activities of the communist authorities seemed to be moving towards ensuring the normalization and stabilization of Jewish life in the city. The synagogue was re-opened. However, facing the increasingly growing anti-Semitism among Poles, which led in 1946 to anti-Jewish riots and the death of more than a dozen representatives of the Jewish minority, the revival of this community proved impossible. An expression of the longing for, and relations of Białystok Jews with this city was the foundation of Kiryat Bialystok in Israel. The consistently pursued policy of the municipal authorities led to the fact that, in the 1970s, so rich and distinc- 
tive in the past 'Jewish landscape' became a landscape of oblivion, in the full sense of the word. Jewish street names were removed, the remaining synagogues changed their functions, and in 1971 the ghetto cemetery in Żabia street was liquidated and replaced by a new park (KLImczuK, A. 2012). A new history of the city was created, in which there was no room for the discussed community any more. This is confirmed even in Białystok guidebooks published in the years of 1950 to 1980 . None of them mention, or just very briefly the former Jewish residents of the city and their culture.

The authorities did not openly conduct a similarly hostile policy against representatives of other nationalities and religions. For instance, in 1962 the Muslims managed to establish a religious community in Białystok, yet we have to remember that they were Polish Tartars, who had been long assimilated in the Polish society, they recognized themselves as Poles and declared their loyalty to Poland. In addition, the establishment of the Muslim community in Białystok in a sense weakened the traditional Muslim centres in Bohoniki and Kruszyniany. In 1981, the city authorities donated a historical house for the needs of the community, which became a House of Prayer and a cultural centre of the community. The reluctant attitude of the authorities towards religious associations manifested itself primarily in not issuing permits for the foundation of new parishes and the erection of temples.

In the 1970s, four new Catholic parishes were established, whereas already existing temples were being used as parish churches, or their construction began in the following decade. Until the political transition of 1989, another 5 parishes were founded, however, in the entire period discussed, the construction of 5 churches was started, of which only 1 was completed (Christ the King's church). In the case of the Orthodox Church, the first 4 parishes after the war were founded in the 1980s. The construction of 2 Orthodox churches was also begun (the churches of the Holy Spirit and the Divine Wisdom).
After 1989, the religious and cultural landscape of the city experienced the biggest changes since the end of World War II. Most noticeable was the progressive sacralisation of urban space associated with the construction of new centres of Christian worship. Until 201620 churches were built, and a few more were planned. 9 Orthodox churches were built or completed ${ }^{5}$ (i.e. 8 parish churches and one chapel of ease), including the largest Orthodox church in Poland, the Church of the Holy Spirit. Also the Muslims acquired a second house of prayer, this time belonging to the Muslim League registered in Poland since 2006. Unfortunately, the project to build a mosque in the city failed since the Muslim community was unable to cope financially and the land had to be sold.

In developing the multicultural identity of the city, activities integrating the community around this issue and allowing the creation of relationships of mutual understanding and tolerance are of paramount importance (SADowski, A. 2013). Białystok also having been heading in this direction in recent years. The first significant initiative in this regard was the turn towards the Jewish cultural heritage and the marking out of the Jewish Heritage Trail in the city space (Figure 1, Photos 1-3). It is an independent social initiative undertaken by volunteers and employees of the University of Białystok affiliated with the Foundation of the University of Białystok. A ceremonial promotion of the trail took place in 2008 (NiziołeK, K. 2008). Hence, the landscape of oblivion is slowly becoming a landscape of remembrance. On the trail, comprising 36 places of interest, there are important historical places (preserved synagogue buildings, old Jewish schools, a hospital, a cemetery) and places commemorating the Holocaust, including the monument of the heroes of the ghetto and the Monument of the Great Synagogue.

\footnotetext{
${ }^{5}$ For comparison, in 1945 , there were 4 Catholic parishes and 3 Orthodox ones within the city limits of present Białystok. The Catholic Church had 4 churches and the Orthodox Church had 4, too. Currently, there are 32 Catholic churches and 13 Orthodox ones.
} 


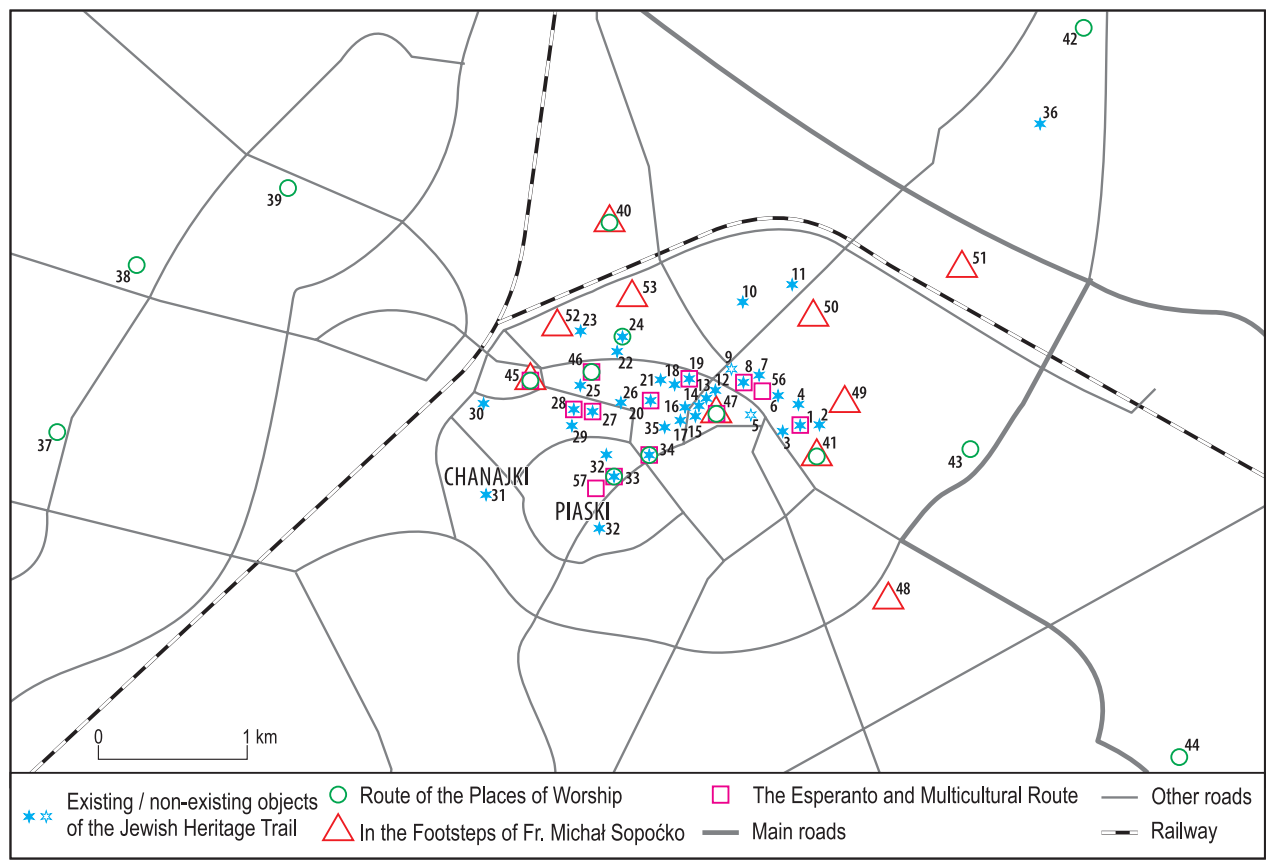

Fig. 1. Attractions and tourist routes associated with religious heritage in Białystok (edited by the authors). A) Objects of the Jewish Heritage Trail: 1 = Cytron Palace (today Historical Museum); 2 = Tobacco Factory of Faiwel Janowski; 3 = Shmuel Synagogue; 4 = Jewish Female Gymnasium of Zinaida Chwoles; 5 = Białystok Palace Theatre; 6 = Jewish Hospital (now Maternity Hospital); $7=$ Białystok Trylling Palace; $8=$ Zygmunt August Gymnasium (now Sigismund Augustus High School); 9 = Sholem Aleichem Library; 10 = TOZ Sanatorium; 11 = The Hebrew Gymnasium (now Municipal Hospital); 12 = Mansion (ul. Sienkiewicza 26A); 13 = Apollo Cinema; 14 = Mansion (ul. Sienkiewicza 26A; now State Theatre Academy); 15 = Gymnasium of Jozef Zeligman, Jozef Lebenhaft and Jakub Dereczynski; 16 = Gilarino Miniature Theatre; 17 = Mansions of Isaac Zabludowski; 18 = Linas Chailim Charity Association; 19 = House of the Zamenhof family; 20 = Monument to Ludwik Zamenhof; 21 = Yitzhak Malmed Plaque; 22 = Druskin Gymnasium; 23 = The Heroes of the Ghetto Uprising Monument; 24 = Cytron Synagogue (now Art Gallery of the Slendzinskis); 25 = Warynskiego Street; $26=$ The Modern Cinema; 27 = House of the Jakub Szapiro family; 28 = Nowik Palace in Białystok; 29 = Tarbut (today Maria Grzegorzewska Craft School); 30 = The Barbican Mission (today Syrena cinema); 31 = Białystok-Chanajki Quarter; 32 = Piaski Quarter; 33 = Rabbinical Cemetery (today Central Park); 34 = Piaskower Synagogue; 35 = The Monument of the Great Synagogue; 36 = The City Hall; 37 = The Jewish Cemetery (Wschodnia Street) and the Cholera Cemetery in Białystok. B) Objects on the Route of the Places of Worship: $38=$ Church of the Resurrection; 39 = Orthodox Church of the Resurrection; 40 = Orthodox Church of the Holy Spirit; 41 = Sanctuary of Divine Mercy; 24 = Cytron Synagogue; 42 = Church of St. Wojciech Bishop and Martyr; 43 = Orthodox Church of Divine Wisdom; 44 = Muslim Prayer House; 45 = Church of the Immaculate Heart of Mary in Dojlidy; 46 = Church of Christ the King and St. Roch; 47 = Orthodox church of St. Nicholas; 48 = Cathedral of the Assumption of the Blessed Virgin Mary; 34 = Piaskower Synagogue; 35 = The Monument of the Great Synagogue. C) In the Footsteps of Fr. Michał Sopoćko: 46 = Church of Christ the King and St. Roch; 48 = Cathedral of the Assumption of the Blessed Virgin Mary; 49 = Chapel of the Sisters of the Shepherdess; $42=$ Church of St. Wojciech Bishop and the Seminary; $50=$ Former building of the Seminary; $51=$ The house of Fr. Sopoćko; 52 = Church of the Sacred Heart of Jesus; $53=$ Monument - cross at the track; $54=$ Chapel of the Sisters of Merciful Jesus; 41 = Sanctuary of Divine Mercy. D) The Esperanto and Multicultural Route: 20 = Monument to Ludwik Zamenhof; $19=$ House of the Zamenhof family; $48=$ Cathedral of the Assumption of the Blessed Virgin Mary; 55 = Guest House; 56 = Centrum Ludwik Zamenhof; 8 = Former gymnasium in which Ludwik Zamenhof studied; 1 = Cytron Palace; 35 = The Monument of the Great Synagogue; $34=$ Piaskower Synagogue; 57 = Sienna Market; 29 = Tarbut Jewish School; 46 = Church of Christ the King and St. Roch; 28 = Nowik Palace in Białystok; 27 = House of the Jakub Szapiro family; $47=$ Orthodox church of St. Nicholas 


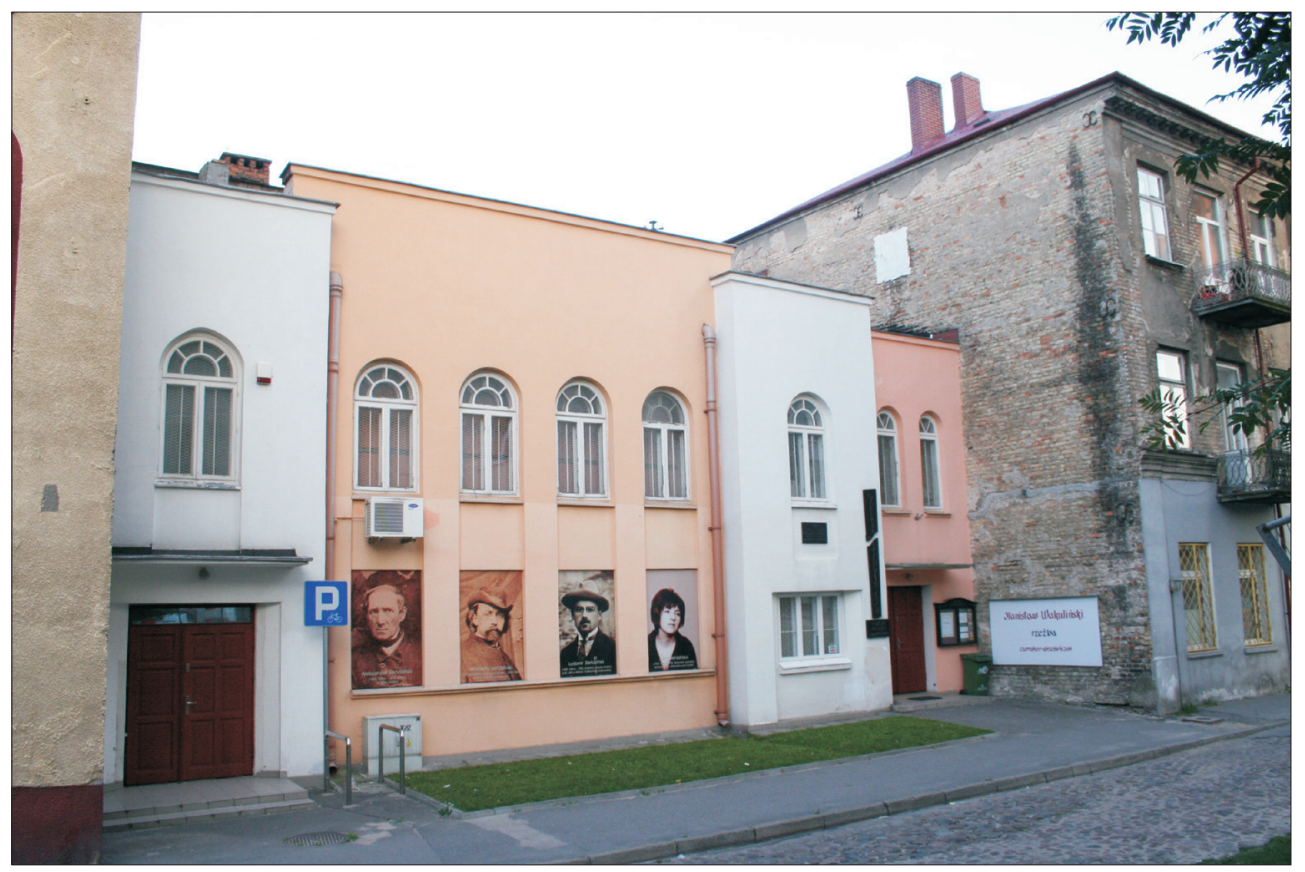

Photo 1. Cytron Synagogue (now Art Gallery of the Slendzinskis) (Photo by Bilska-Wodecka, E.)

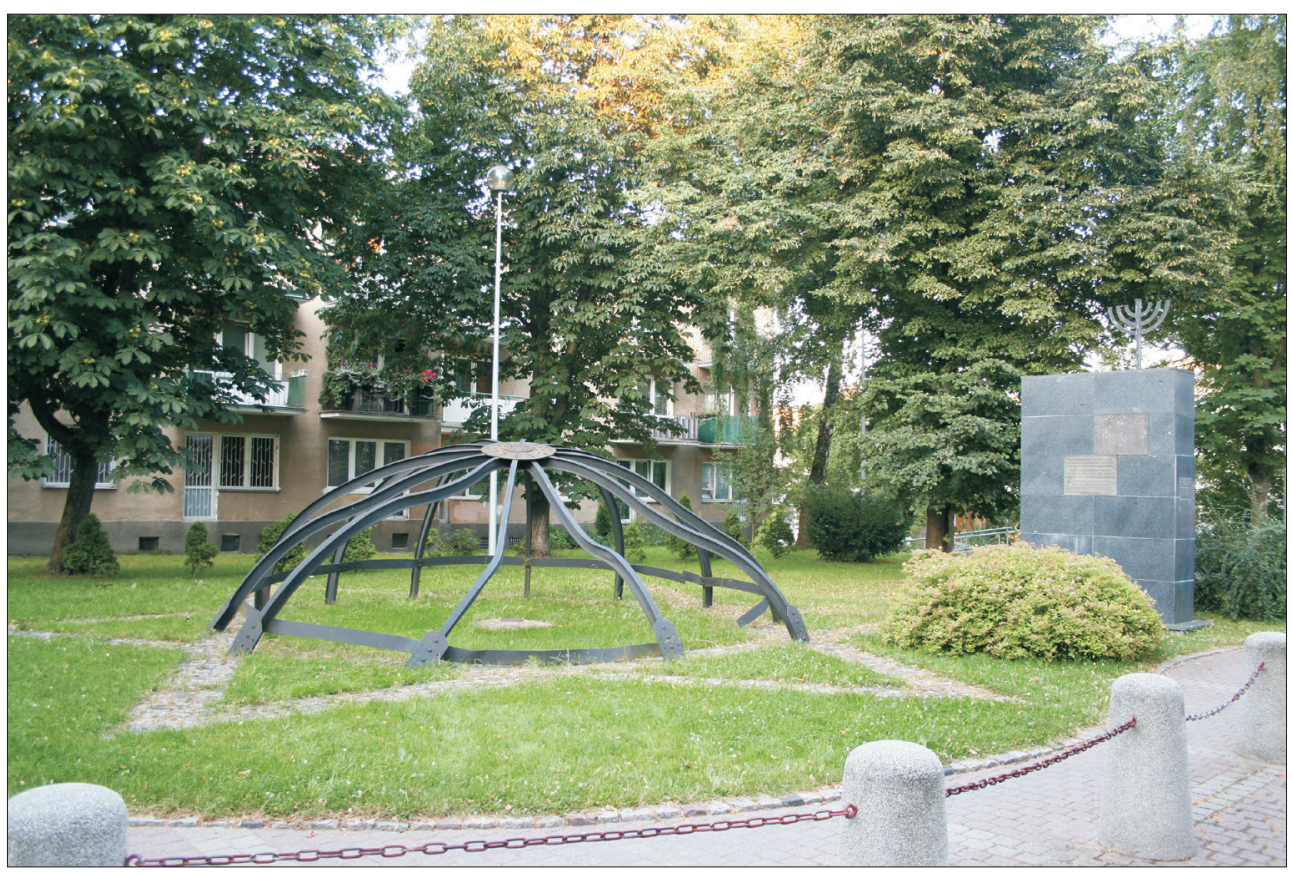

Photo 2. The Monument of the Great Synagogue (Photo by Bilska-Wodecka, E.) 


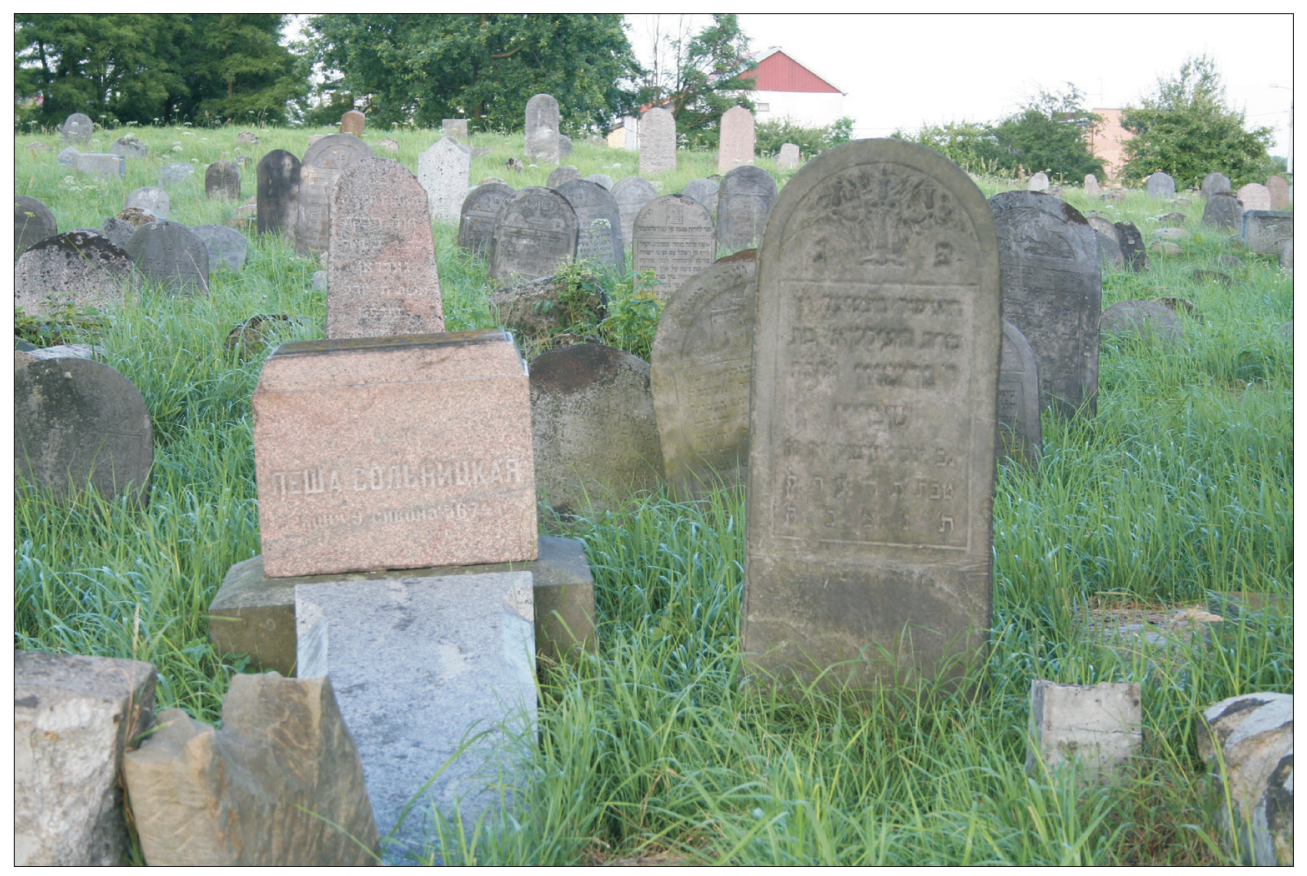

Photo 3. The Jewish Cemetery (Wschodnia street) (Photo by Bilska-WodeckA, E.)

Next to the Jewish Trail, other thematic routes focusing on the multicultural character of the city were also created, e.g. the Ludwik Zamenhof and Many Cultures Trail or the Białystok Temples Trail, showing the city's religious and architectural diversity (Photo 4-5).

Interesting buildings and places, neatly crafted boards, interesting plastic solutions (e.g. murals), along with the information they convey, make the trails an attractive offer for both residents and tourists. In the post-war period Białystok also became the Tatar capital of Poland; numerous cultural events that allow to get to know the Tatar heritage are held here, including, since 2008, the annual Podlasie Days of Muslim Culture. In the Historical Museum, the only Polish permanent exhibition of memorabilia of their culture is open for visitors. In a sense, the trail of Father Michał Sopoćko, a great supporter of the cult of Divine Mercy, who lived in Białystok and was buried there, also fits in with the city's multiculturalism.

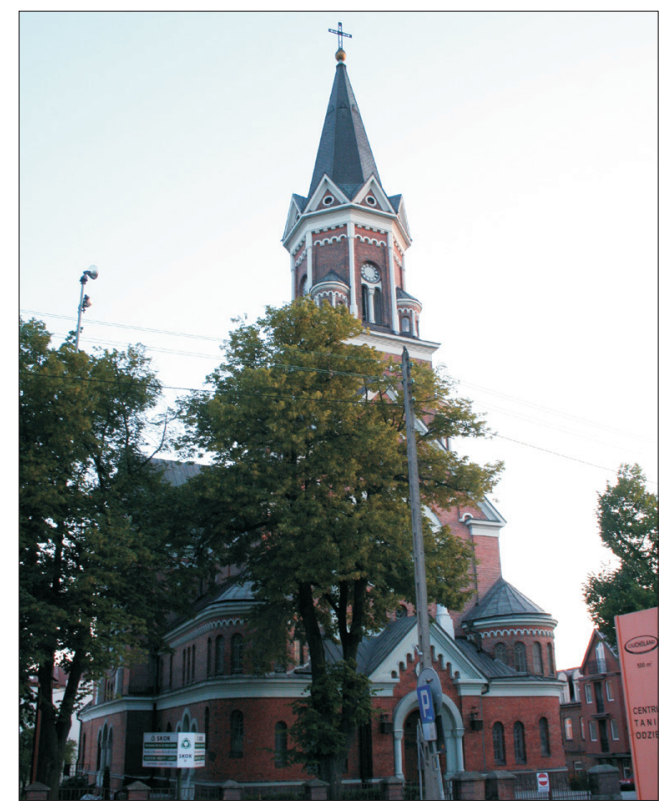

Photo 4. Church of St. Wojciech Bishop and Martyr (Photo by Bilska-Wodecka, E.) 


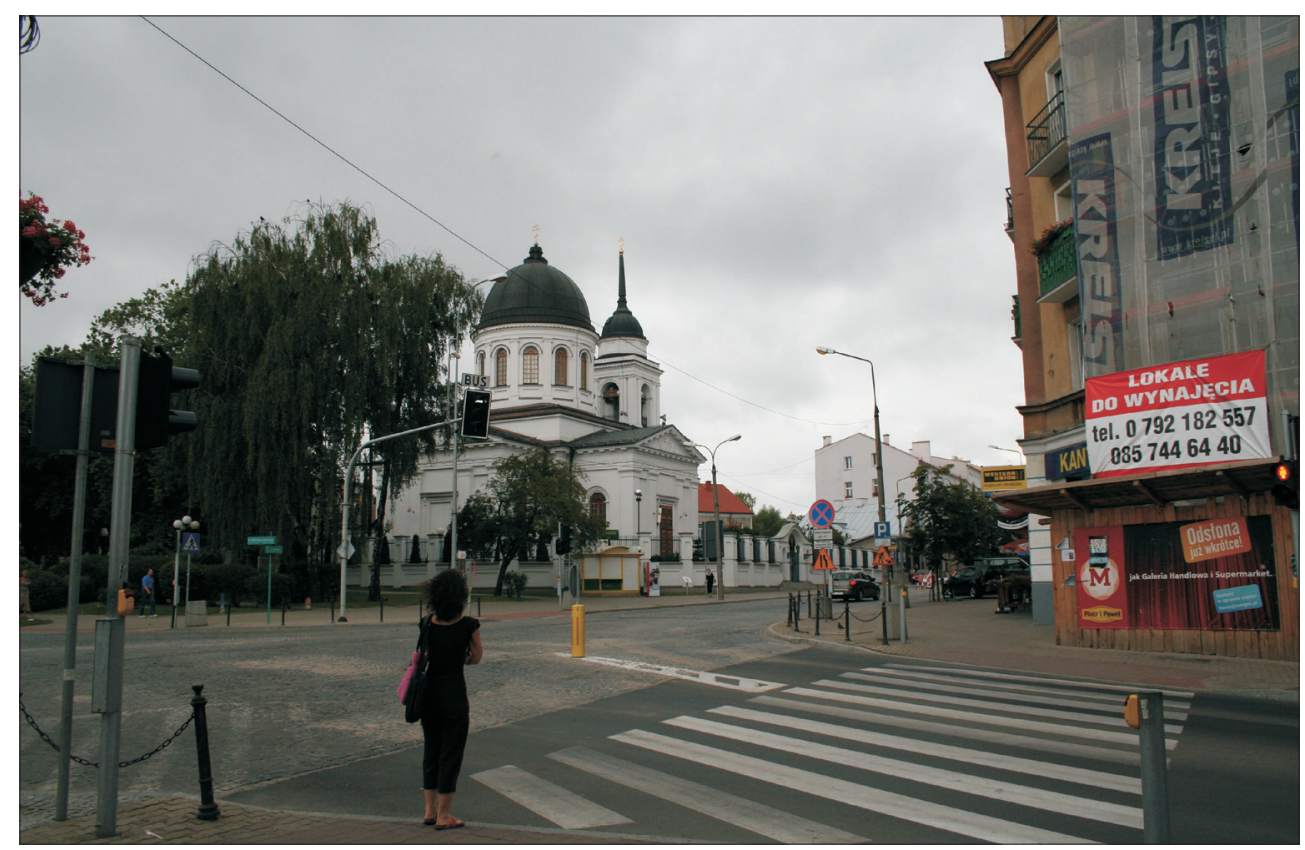

Photo 5. Orthodox church of St. Nicholas (Photo by Bilska-WodeckA, E.)

\section{Conclusions}

Multiculturalism provides a great opportunity for Białystok, enabling it to become known in an increasingly globalized and uniformized mass-culture and, on the other hand, increasingly diversified world. The transition from multiculturalism bringing about isolation and division to unity in diversity is not easy, but it seems possible, which we attempted to demonstrate in this article. It is also a counterweight to the aggressive nationalistic behaviour, many examples of which can also be provided from the recent history of Białystok. Offensive slogans raised against the Jews and Chechens, setting fire to the Muslim Cultural Centre and, unfortunately, numerous attacks on foreigners are just some of the examples that will not bring fame to the city (SAcharczuK, J. 2014). Its cultural landscape, the landscape of memory reminding of what was and what is, bearing witness to past events and people differing in many ways, yet living in one space, is a recorded lesson of history and the present, from which a careful observer can learn a lot to better understand the reality that surrounds them.

Białystok is an example of a city in which, after the political changes in 1989, the potentials of both the past and the contemporary cultural diversity of its inhabitants began to be noticed. What was hidden in the communist period, what was attempted to be forgotten, and even 'erased' from the urban landscape, has become an asset making it possible to build the city's identity and its image. Similar activities can be observed in other urban centres in Poland, for example in Katowice, Łódź and Wrocław. Post-Jewish or post-German heritage is no longer shameful, and the new historical policy provides a different perspective from which to view the history of these cities.

Białystok, still a typical Jewish town at the beginning of the $20^{\text {th }}$ century, has great opportunities to use this fact in creating a tour- 
ist strategy for the city and the region. This is evidenced by the already established tourist routes, designed not only to preserve but also to expose remembrance in the space of this landscape. An undisputed value of Białystok is also the culture of the remaining, still present in the city, religious communities and ethnic minorities. There is no other city in Poland where there are more than a dozen orthodox churches, including one of the most important temples - St. Nicholas' church. Architecturally interesting catholic churches and sanctuaries attracting pilgrims complete the picture. Podlasie is also the only region in Poland with a historically shaped Muslim community of Polish Tatars. Thus, the cultural potential of the city is so rich that it can (and increasingly is) constitute a base for the development of tourism, not only on a local, but also nationwide, and even international scale. Contemporary Białystok is promoted as a city of tourist interest precisely because of its unique cultural values, and not only (as was the case in the postwar period, until the 1990s) because of one building that is worth seeing, i.e. the Branicki palace. In the case of Białystok, the analysis of multiculturalism in the context of national heritage seems most appropriate.

Multiculturalism is important for the promotion of tourism in the entire Podlasie region (Duridywka, M. and Kociszewski, P. 2013). Tourism is closely linked to the cultural heritage of the place. As suggested by many authors, traces of multiculturalism from the past can be a factor activating the promotion of tourism and tourist movement, if appropriate steps are taken (CAFFYN, A. and Lutz, J. 1999; Pizam, A. 1999; Reisinger, Y. 2009; Duridywka, M. and Kociszewski, P. 2013; Puchnarewicz, E. 2010). Cultural tourism, tourism related to places of remembrance is one of the most dynamically developing forms of travelling today. The presented diversity of Białystok may be the basis for the development of tourism related to the history and culture of the Jewish, Muslim, Orthodox and other communities in the city.

The presence of heritage of ethnic and religious minorities is undoubtedly a great asset in the planning of further development and popularization of cultural tourism in Białystok. As the experience of the past shows, its future depends mainly on political factors. The majority of councillors from the right-wing party in the city council may have the effect of depriving the initiatives/events that promote the multicultural heritage of the city of funding and destroying many civic initiatives in this respect.

\section{REFERENCES}

Arneil, B. 2006. Diverse Communities: The Problem with Social Capital. Cambridge, Cambridge University Press.

Arneil, B. and MacDonald, F. 2016. Multiculturalism and the Social Sphere. In The Ashgate Research Companion to Multiculturalism. Ed.: Ivison, D., London, Routledge, 95-117.

Banting, K. and KymlickA, W. 2006. Multiculturalism and the Welfare State: Recognition and Redistribution in Contemporary Democracies. Oxford, Oxford University Press.

BнікнU, P. 2002. Rethinking Multiculturalism: Cultural Diversity and Political Theory. Boston, Harvard University Press.

Bilska-Wodecka, E. 2012. Człowiek religijny i związki wyznaniowe w przestrzeni miasta $w$ XX i na poczatku $X X I$ wieku (Religious man and religious associations in the city space in the $20^{\text {th }}$ and at the beginning of the $21^{\text {st }}$ century). Kraków, IGiGP UJ.

Byelostok (Polish: Białystok), 2002-2011. In Jewish Encyclopedia. http://www.jewishencyclopedia. com/articles/3255-bialystok-lithuania\#anchor4 (retrieved 20.01.2017)

CAfFyn, A. and Lutz, J. 1999. Developing the heritage tourism product in multi-ethnic cities. Tourism Management 20. (2): 213-221.

Czyżewski, P. 1999. Powstanie cerkwi białostockiej (The rise of the Białystok Orthodox church). Białostocczyzna 4. (56): 11-18.

DAcewicz, L. 1997. Nazewnictwo Żydów w XVIIIwiecznym Białymstoku (The naming of Jews in $18^{\text {th }}$ century Białystok). Białostocczyzna 4. (56): 25-31.

DolińsKa, K. and MaKaro, J. 2013. O wielokulturowości monokulturowego Wrocławia (On the multiculturality of monocultural Wrocław). Wrocław, Wydawnictwo Uniwersytetu Wrocławskiego.

Duridywka, M. and Kociszewski, P. 2013. Wielokulturowość Podlasia i możliwości jej wykorzystania w turystyce (Multiculturality of Podlasie region and possibilities of its use in tourism). Turystyka Kulturowa 6. 5-29. 
Florida, R. 2002. The Rise of the Creative Class. And How It's Transforming Work. Leisure and Everyday Life. New York, Basic Books.

Hero, R. and Preuhs, R. 2006. Multiculturalism and Welfare Policies in the USA: A State-Level Comparative Analysis. In Multiculturalism and the Welfare State: Recognition and Redistribution in Contemporary Democracies. Eds.: BAnTing, K. and Kymlicka, W., Oxford, Oxford University Press, 121-151.

Irimiás, A. and Michalkó, G. 2013. Religious tourism in Hungary - an integrative framework. Hungarian Geographical Bulletin 62. (2): 175-196.

Kalina, M. 1995. Polonizacja Cerkwi prawosławnej w województwie białostockim (1918-1939) (The Polonization of the Orthodox Church in Białystok [1918-1939]). Białoruskie Zeszyty Historyczne 2. (4): 74-105.

KLimczuK, A. 2012. History of the Jews in the Podlasie Region. We Have Lived Together for Centuries: from Cultural Diversity to Multiculturalism. Bottom-up Techniques of Social Capital Building. In Wielokulturowe Podlasie w Unii Europejskiej. Eds.. Wrońska, I. and RusiŁowicz, M., Białystok, Prawo i Partnerstwo, 152-163.

Kobrin, R. 2014. Żydowski Białystok $i$ jego diaspora (Jewish Białystok and its diaspora). Sejny, Fundacja Pogranicze.

LAden, A.S. and Owen, D. eds. 2007. Multiculturalism and Political Theory, Cambridge, Cambridge University Press.

Łaguna-RAszkiewicz, K. 2012. Pamięć społeczna o relacjach polsko-żydowskich w Białymstoku: perspektywa edukacji międzykulturowej (Social memory of Polish-Jewish relations in Białystok: the perspective of inter-cultural education). Toruń, Wydawnictwo Naukowe Grado,

Lechowski, A. 2009. Białystok. Przewodnik historyczny. (Białystok. A historical guidebook). Benkowski Publishing.

MaŁeK, A. 1999. Białystok pod zaborem pruskim 1795-1807 (Białystok under Prussian rule 17951807). Białostocczyzna 4. (56): 19-24.

Marotta, V. 2007. Multicultural and Multiethnic Cities in Australia, Ethnic Landscapes in an Urban World. Research in Urban Sociology 8. (6): 41-62.

Miśkiewicz, A. 2011. Tatarzy polscy w latach 19451985. Zarys historyczny (Polish Tatars in the years 1945-1985. A historical overview). Studia Podlaskie 3. 99-137.

Modood, T. 2007. Multiculturalism: A Civic Idea. London, Polity.

NizıoŁeK, K. 2008. Szlak Dziedzictwa Żydowskiego w Białymstoku (Polish Tatars in the years 1945-1985. A historical overview). In Historia, pamięć, tolerancja. Nauczanie o wielokulturowości i lokalnej historii.
Eds.: NizioŁek, K. and Poczykowski, R., Białystok, Fundacja Uniwersytetu w Białystoku, 135-140.

Pasieka, A. 2013. Wielokulturowość po polsku. O polityce wielokulturowości jako mechanizmie umacniania polskości (Multiculturalism the Polish way. On the policy of multiculturalism as a mechanism for reinforcing Polishness). Kultura $i$ społeczeństwo 3. 129-155.

Phillips, A. 2007. Multiculturalism without Culture, Princeton, NJ, Princeton University Press.

Pizam, A. 1999. Cross-cultural Tourist Behavior. In Consumer Behavior in Travel and Tourism. Eds.: Pizam, A. and Mansdeld, Y., Binghampton, Haworth, 393-411.

Puchnarewicz, E. 2010. Znaczenie wielokulturowości $\mathrm{w}$ turystyce $\mathrm{u}$ progu XXI wieku (The importance of multiculturalism in tourism at the turn of the $21^{\text {st }}$ century). In Wielokulturowość $w$ turystyce. Ed.: Puchnarewicz, E., Krakow, Wyższa Szkoła Turystyki i Języków Obcych, 15-33.

ReIsINGER, Y. 2009. International Tourism: Cultures and Behavior. Oxford, Butterworth-Heinemann.

Rex, J. and Singh, G. 2003. Multiculturalism and Political Integration in Modern Nation-States: Thematic Introduction. International Journal on Multicultural Societies 5. (1): 3-19.

SacharczuK, J. 2014. Kwestie społeczne wynikające z wielokulturowości z uwzględnieniem sytuacji Białegostoku (Social issues arising from multiculturalism taking into account the situation of Białystok). In Od wielokulturowości miejsca do międzykulturowości relacji społecznych. Eds.: Nikitorowicz, J., MuszyńsKa, J. and BoćwińskAKILUK, B., Warsaw, Wydawnictwo Akademickie Żak, 24-38.

SADowska, J. 2015. Społeczność żydowska w Białymstoku w latach 1944-1950 (Jewish community in Białystok in the years 1944-1950). Jewish History Quarterly 3. 515-531.

Sadowski, A. 2006. Białystok. Kapitat społeczny mieszkańców miasta (Social capital of the city's inhabitants). Białystok, Wydawnictwo Wyższej Szkoły Ekonomicznej w Białymstoku.

SADowski, A. 2013. Miejsce społeczności żydowskiej w strukturze Białegostoku jako odradzającego się miasta wielokulturowego Białystok (The place of Jewish community in the structure of Białystok as a reborn multicultural city). Studia MigracyjnePrzeglad Polonijny 47. (1): 225-242.

Shmulewitz, I. 1982. Bialystok - A Historical Survey. In The Bialystoker Memorial Book / Der Bialystoker Jizkor Buch. New York, 3-5.

Sosna, G. and Troc-Sosna, A. 2004. Cerkiewna własność ziemska na Białostocczyźnie w XV-XX wieku. Zbiór materiałów (Orthodox Church landed estate in Białystok region in the $15^{\text {th }}-20^{\text {th }}$ centuries. A collection of materials). Diecezja warszawsko-bielska i białostocko-gdańska, Białystok, Orthdruk. 
Strategia Rozwoju Miasta Białegostoku na Lata 2011-2010 plus (The strategy for the development of the city of Białystok for the years 2011-2020 plus). 2010, Białystok, City Hall in Białystok.

The Bialystoker Memorial Book / Der Bialystoker Jizkor Buch. New York, 3-5.

TIRYAKIAN, E.A. 2003. Assessing multiculturalism theoretically: E pluribus unum, Sic et Non. International Journal on Multicultural Societies 5. 20-39.

Trotman, C. 2002. Multiculturalism: Roots and Realities. Indiana, Indiana University Press.
Wiśniewski, T. 1992. Bóżnice Białostocczyzny (Shuls of Bialystok region). Heartland of the Jewish life: synagogues and Jewish communities in Biatystok region. Białystok, David.

Wyszowska, I. and Jędrysiak, T. 2014. Dziedzictwo kulturowe Ludwika Zamenhofa. Idea przeszłości czy przyszłości? (The Cultural Heritage of Ludwik Zamenhof. An idea of the past or the future?) Turystyka Kulturowa 6. 70-89. www.turystykakulturowa-org 
